Article

\title{
Proteomics and Toxicity Analysis of Spinal-Cord Primary Cultures upon Hydrogen Sulfide Treatment
}

\author{
Viviana Greco ${ }^{1,2,+}$, Alida Spalloni ${ }^{3,+}$, Victor Corasolla Carregari ${ }^{1,2}$, Luisa Pieroni ${ }^{4}$, \\ Silvia Persichilli ${ }^{1,2}$, Nicola B. Mercuri ${ }^{5,6}$, Andrea Urbani ${ }^{1,2}$ and Patrizia Longone ${ }^{3, *}$
}

1 Institute of Biochemistry and Clinical Biochemistry, Università Cattolica del Sacro Cuore, 00168 Rome, Italy; vivianagreco82@yahoo.it (V.G.); corasolla@gmail.com (V.C.C.); silvia.persichilli@unicatt.it (S.P.); andrea.urbani@unicatt.it (A.U.)

2 Department of Laboratory Diagnostic and Infectious Diseases, Fondazione Policlinico Universitario Agostino Gemelli-IRCCS, 00168 Rome, Italy

3 Department of Experimental Neuroscience, Molecular Neurobiology Unit, Fondazione Santa Lucia, 00143 Rome, Italy; a.spalloni@hsantalucia.it

4 Department of Experimental Neuroscience, Proteomics and Metabonomics Unit, Fondazione Santa Lucia-IRCCS, 00143 Rome, Italy; 1.pieroni@hsantalucia.it

5 Department of Systems Medicine, Policlinico Universitario "Tor Vergata", University of Rome "Tor Vergata", 00133 Rome, Italy; mercurin@med.uniroma2.it

6 Department of Experimental Neuroscience, Experimental Neurology Unit, 00143 Rome, Italy

* Correspondence: p.longone@hsantalucia.it

+ These authors contributed equally to this work.

Received: 12 April 2018; Accepted: 7 July 2018; Published: 10 July 2018

\begin{abstract}
Hydrogen sulfide $\left(\mathrm{H}_{2} \mathrm{~S}\right)$ is an endogenous gasotransmitter recognized as an essential body product with a dual, biphasic action. It can function as an antioxidant and a cytoprotective, but also as a poison with a high probability of causing brain damage when present at noxious levels. In a previous study, we measured toxic liquoral levels of $\mathrm{H}_{2} \mathrm{~S}$ in sporadic amyotrophic lateral sclerosis (ALS) patients and in the familial ALS (fALS) mouse model, SOD1G93A. In addition, we experimentally demonstrated that $\mathrm{H}_{2} \mathrm{~S}$ is extremely and selectively toxic to motor neurons, and that it is released by glial cells and increases $\mathrm{Ca}^{2+}$ concentration in motor neurons due to a lack of ATP. The presented study further examines the effect of toxic concentrations of $\mathrm{H}_{2} \mathrm{~S}$ on embryonic mouse spinal-cord cultures. We performed a proteomic analysis that revealed a significant $\mathrm{H}_{2} \mathrm{~S}$-mediated activation of pathways related to oxidative stress and cell death, particularly the Nrf-2-mediated oxidative stress response and peroxiredoxins. Furthermore, we report that $\mathrm{Na}_{2} \mathrm{~S}$ (a stable precursor of $\mathrm{H}_{2} \mathrm{~S}$ ) toxicity is, at least in part, reverted by the Bax inhibitor V5 and by necrostatin, a potent necroptosis inhibitor.
\end{abstract}

Keywords: apoptosis; hydrogen sulfide; motor neuron; necroptosis; proteomics

\section{Introduction}

In 2015 [1], we showed that hydrogen sulfide $\left(\mathrm{H}_{2} \mathrm{~S}\right)$ reaches toxic levels in the cerebrospinal fluid (CSF) of sporadic amyotrophic lateral sclerosis (ALS) patients. Furthermore, we documented a correlation between the concentration of $\mathrm{H}_{2} \mathrm{~S}$ and the site of disease onset, with significantly higher levels of $\mathrm{H}_{2} \mathrm{~S}$ in the limb-onset group compared to the bulbar-onset group. In the same work, we demonstrated that (i) neuronal tissues from the familial ALS (fALS) mouse model, SOD1G93A contain high levels of $\mathrm{H}_{2} \mathrm{~S}$ compared to the related controls; (ii) glial cells are the major source of $\mathrm{H}_{2} \mathrm{~S}$, since halting their growth in vitro resulted in a significant decrease in $\mathrm{H}_{2} \mathrm{~S}$ concentration in the cell media; (iii) $\mathrm{H}_{2} \mathrm{~S}$ is toxic to motor neurons, as compared to gamma-aminobutyric acid+ (GABA+) neurons, partly through the a-amino-3-hydroxy-5-methyl-4-isoxazole propionic acid (AMPA) 
receptor; and (iv) $\mathrm{H}_{2} \mathrm{~S}$ increases $\mathrm{Ca}^{2+}$ concentration in motor neurons, triggered by a decrease in ATP production [1].

Hydrogen sulfide, like carbon monoxide and nitric oxide, is now recognized as a cellular gaseous mediator and a neurotransmitter [2-4]. It is produced via cysteine catabolism by the cytoplasmic enzymes, cystathionine- $\beta$-synthase (CBS) and cystathionine- $\gamma$-lyase (CSE), and also via 3-mercaptopyruvate catabolism by 3-mercaptopyruvate sulfurtransferase (3-MST) [5]. It is a challenging molecule. At physiological concentrations ( $\mathrm{nM}$ to low- $\mu \mathrm{M}), \mathrm{H}_{2} \mathrm{~S}$ produces beneficial effects; however, when it reaches higher concentrations, as the one that we measured in the ALS patients, it can have harmful actions [1]. Indeed, on one hand, $\mathrm{H}_{2} \mathrm{~S}$ showed protective abilities in cellular and animal models of Parkinson's disease (PD) and Alzheimer's disease (AD). It can revert 6-hydroxydopamine (6-OHDA)-induced neuronal loss, suggesting a protective effect of $\mathrm{H}_{2} \mathrm{~S}$ in $\mathrm{PD}$ [6]. In $\mathrm{AD}, \mathrm{H}_{2} \mathrm{~S}$ showed the ability to ameliorate $\mathrm{A} \beta$-induced cell apoptosis [7], improve spatial memory, and reduce the production of $A \beta$ in the human amyloid precursor protein (Mo/HuAPP695swe) and a mutant human presenilin 1 (PS1-dE9) (APP/PS1) AD mouse model [8]. On the other hand, it is one of the major toxic gases with fatal effects if inhaled $[9,10]$. At high concentrations ( $300 \mu \mathrm{M}$ and $1 \mathrm{mM})$, it causes an N-methyl-D-aspartate (NMDA) receptor-independent neuronal death via the activation of apoptotic mechanisms and the MEK/ERK pathway [11], as well as through a glutamate-mediated activation of calpains and the destabilization of the lysosomal membrane in cortical neurons [12].

As a follow-up to our previous work [1], here we examined the potential death mechanisms activated by $\mathrm{H}_{2} \mathrm{~S}$ on mixed primary mouse spinal-cord cultures. In this work, we used the proteomic approach to examine (unravel) how protein expression changes in $\mathrm{H}_{2} \mathrm{~S}$-treated and $\mathrm{H}_{2} \mathrm{~S}$-untreated primary spinal-cord cultures down to the cellular level. The proteomic analysis highlighted a significant perturbation of the Nrf-2-mediated oxidative stress response, peroxiredoxins, and hypoxia-inducible factors. Moreover, we showed that, at relatively high concentrations (100 $\mu \mathrm{M}$ and $200 \mu \mathrm{M}), \mathrm{H}_{2} \mathrm{~S}$ activated, in primary spinal-cord cultures, cellular pathways linked to apoptosis and necrosis. Specifically $\mathrm{H}_{2} \mathrm{~S}$-induced neuronal death was, in part, neutralized by the Bax inhibitor V5 and by necrostatin, a necroptosis inhibitor.

\section{Material and Methods}

\subsection{Primary Spinal-Cord Culture}

Mixed spinal cords were prepared from 13.5-day-old embryos of C57BL6xSJL mice housed at the Fondazione Santa Lucia animal facility (Protocol Number 93O/2017-PR; Spalloni et al., 2004). After dissection, the spinal cord cultures were plated on glass cover slips, and were maintained in Neurobasal medium supplemented with B-27 and $0.5 \mathrm{mM}$ glutamine. The medium was replaced with Neurobasal supplemented with B-27, and was changed every 3 days [13].

\subsection{Proteomic Analysis}

Following the toxicity protocol, spinal-cord cultures were washed three times in PBS, and cell lysates were prepared by solubilizing the cells in RIPA buffer (150 mM NaCl, $1 \mathrm{mM}$ EDTA, $0.5 \%$ sodium deoxycolate, $0.1 \%$ sodium dodecyl sulfate (SDS) SIGMA-Aldrich, Milan, Italy) with freshly added protease and phosphatase inhibitors (protease inhibitor cocktail; SIGMA).

Briefly, extracts derived from the spinal-cord culture were precipitated with a cold mix of ethanol, methanol, and acetone (ratio 2:1:1, v/v), then dissolved in $6 \mathrm{M}$ urea and $100 \mathrm{mM}$ Tris at $\mathrm{pH} 7.5$, and digested 50:1 ( $w / w$ ) with sequence-grade trypsin (Promega, Madison, WI, USA) at $37^{\circ} \mathrm{C}$ overnight after reduction with $10 \mathrm{mM}$ dithiothreitol (DTT) and alkylation with $20 \mathrm{mM}$ Iodoacetamide (IAA). The reaction was stopped by adding Trifluoroacetic acid (TFA) to a final concentration of $0.1 \%$.

Label-free proteomic analysis was performed, as previously described by Piras et al. [14,15], with some modifications. Firstly, $100 \mathrm{fmol} / \mu \mathrm{L}$ of digestion of enolase from Saccharomyces cerevisiae was added to each sample as an internal standard, and then, separation of tryptic peptides was performed 
on an ACQUITY MClass System (Waters Corporation, Waters S.p.A., Sesto San Giovanni, Italy). Each digested sample $(0.25 \mu \mathrm{g})$ was loaded onto a Symmetry C18 $5 \mu \mathrm{m}, 180 \mu \mathrm{m} \times 20 \mathrm{~mm}$ precolumn (Waters Corporation, Waters S.p.A., Sesto San Giovanni, Italy), and was subsequently separated by a $90-\mathrm{min}$ reversed-phase gradient at $300 \mathrm{~nL} / \mathrm{min}$ (linear gradient, 2-85\% $\mathrm{CH}_{3} \mathrm{CN}$ over $90 \mathrm{~min}$ ) using an HSS T3 C18 $1.8 \mu \mathrm{m}, 75 \mu \mathrm{m} \times 150 \mathrm{~mm}$ nanoscale liquid chromatography (LC) column (Waters Corporation) maintained at $40{ }^{\circ} \mathrm{C}$. The separated peptides were analyzed using a high-definition Synapt G2-Si mass spectrometer (Waters Corporation, Waters S.p.A., Sesto San Giovanni, Italy), directly coupled to the chromatographic system. Differential protein expression was evaluated with a data-independent acquisition (DIA) of shotgun proteomic analysis using expression configuration mode $\left(\mathrm{MS}^{\mathrm{E}}\right)$. The mass spectrometer operated in "expression mode" switching between low $(4 \mathrm{eV})$ and high (15-40 eV) collision energies on the gas cell, using a scan time of $1.5 \mathrm{~s}$ per function over 50-2000 m/z. The processing of low and elevated energy, added to the data of the reference lock mass ([Glu1]-Fibrinopeptide B Standard, Waters Corporation, Waters S.p.A., Sesto San Giovanni, Italy), provided a time-aligned inventory of accurate mass-retention time components for both the low- and elevated-energy exact mass retention time (EMRT). Each sample was run in four technical replicates.

\subsection{Bioinfomatic Analysis}

The analysis of differentially expressed proteins was performed according to Silva et al. [16] and Visser et al. [17]. Continuum LC-MS data from the four replicate experiments for each sample were processed for qualitative and quantitative analysis using the ProteinLynx Global Server version 3.0.1 software (PLGS, Waters Corporation, Waters S.p.A., Sesto San Giovanni, Italy). The qualitative identification of proteins was obtained by searching the Mus musculus database (UniProt KB/Swiss-Prot Protein Knowledgebase restricted to Mus musculus taxonomy) to which the sequence from Saccharomyces cerevisiae enolase (UniProtKB/Swiss-Prot AC: P00924) was appended.

Search parameters were set as the following: automatic tolerance for precursor ions and for product ions, minimum three fragment ions matched per peptide, minimum seven fragment ions matched per protein, minimum two peptides matched per protein, one missed cleavage, carbamydomethylation of cysteines and oxidation of methionines as fixed and variable modifications, and false positive rate (FPR) of the identification algorithm under $1 \%$ and $100 \mathrm{fmol}$ of the enolase set as calibration protein concentration. The most reproducible proteotypic peptides for retention time and intensity of enolase digestion $(m / z$ 745.43, $m / z$ 814.49, $m / z 1288.70, m / z 1416.72, m / z 1578.80$, and $m / z$ 1840.89) were used to normalize the table of EMRTs. The expression analysis was performed considering technical replicates available for each experimental condition (i.e., untreated and treated with $\mathrm{H}_{2} \mathrm{~S}$, three biological replicates, four technical replicates) following the hypothesis that each group was an independent variable. The identification of protein was based on the detection of more than two fragment ions per peptide, and more than two peptides measured per protein. The list of normalized proteins was screened according to the following criteria: protein identified in at least three out of four runs of the same sample with a fold change of regulation higher than $\pm 20 \%$; only modulated proteins with $0<p<0.05$ were considered significant.

\subsection{Protein Ontologies and Network Analysis}

To identify biologically relevant molecular pathways, the proteomic datasets were analyzed using a bioinformatic analysis tool based on QIAGEN'S Ingenuity Pathway Analysis (QIAGEN'S Ingenuity Pathway Analysis, Ingenuity Systems, http:/ / www.qiagen.com/ingenuity). This allowed exploring functional associations relevant to the experimental results. The analysis parameters were set as the following: direct and indirect relationships, endogenous chemical substances included, all molecules and/or relationships considered as the summary filter. The most significant categories associated with the loaded datasets were identified by calculating their significance ( $p$-value, Fischer test). A $p$-value threshold was set at 0.05 , which showed the probability of association between genes/proteins present in the datasets and each pathway (canonical pathway, top tox list, and biological function). 


\subsection{Toxicity Experiments}

Spinal-cord cultures were exposed to the $\mathrm{H}_{2} \mathrm{~S}$ donor, $\mathrm{Na}_{2} \mathrm{~S}$ (SIGMA-Aldrich, Milan, Italy), following the same protocol described in Davoli et al., [1]. All experiments were performed between 10 and 12 days in vitro (DIV). For imaging experiments, cells were plated on 13-mm cover glasses. At 10 DIV, the cells were pre-exposed to the BAX Inhibiting Peptide V5 (SIGMA-Aldrich, Milan, Italy; $50 \mu \mathrm{M}$ ) or necrostatin-1 (Merck S.p.a., Roma, Italy; 5 and $15 \mu \mathrm{M}$ ) for $1 \mathrm{~h}$, and then co-exposed to $100 \mu \mathrm{M}$ and $200 \mu \mathrm{M} \mathrm{Na} 2 \mathrm{~S}$ for $18 \mathrm{~h}$. After $18 \mathrm{~h}$, the cells were fixed in paraformaldehyde (4\%). To visualize motor neurons, cultures were stained with SMI-32 (Covance, Princeton, NJ, USA; 1:1000), and nuclei were stained with Hoechst 33342 (SIGMA-Aldrich, Milan, Italy). SMI-32-positive cells were quantified by direct counting, and their number was normalized to the untreated spinal-cord preparation. For toxicity experiments, we performed a Student's $t$-test, setting the significance to $p<$ 0.05 .

\section{Results}

\subsection{Proteome Profiling Using Label-Free Proteomics Analysis}

To understand the effects of $\mathrm{H}_{2} \mathrm{~S}$-mediated toxicity on neuronal cultures, we performed a deep proteomic investigation in order to obtain the expression profile of proteins whose levels change in response to treatment with $\mathrm{Na}_{2} \mathrm{~S}$. $\mathrm{Na}_{2} \mathrm{~S}$, like NaHS, is water-soluble, and is widely used in experimental conditions as an $\mathrm{H}_{2} \mathrm{~S}$ donor [18-20].

To investigate the different protein profiles with and without $\mathrm{Na}_{2} \mathrm{~S}$, we used protein extracts from spinal-cord cultures not treated and treated with $\mathrm{Na}_{2} \mathrm{~S}$ at a concentration of $200 \mu \mathrm{M}$, in which the cytotoxicity of motor neurons was markedly enhanced, as we previously demonstrated in Davoli et al. [1]. The comparative proteome analysis was performed using $\mathrm{MS}^{\mathrm{E}}$ isotope label-free profiling. Quality control measures were performed on the analytical replicates to determine the analytical reproducibility of the mass measurement and chromatographic retention time of each peptide (data not shown).

As thoroughly described in Section 2, using this approach, we identified a total of 316,278 molecular spectral features (EMRTs) and 209 differentially expressed proteins across both conditions of the experimental dataset (not treated vs. $\mathrm{Na}_{2} \mathrm{~S}$ ).

\subsection{Expression of Inflammation and Oxidative Stress-Related Pathways Is Modified after $\mathrm{H}_{2} \mathrm{~S}$ Treatment}

To gain a comprehensive view of the putative cellular and molecular networks in which the identified proteins might be involved, we analyzed our proteomic datasets with a bioinformatic approach.

According to the parameters described in the Section 2, QIAGEN's Ingenuity Pathway Core Analysis revealed inflammation-related pathways that were most significantly perturbed in the dataset of interest. Particularly, this unbiased systems-biology approach identified significant differential expression of proteins involved in the Nrf-2-mediated oxidative stress response canonical pathway $\left(p=4.30 \times 10^{-11}\right)$. Likewise, the Nrf-2-mediated oxidative stress response was identified as one of the most altered among the top toxic pathways $\left(p=4.98 \times 10^{-14}\right)$. Similarly, pathways related to cell-death processes, among the disease-related pathways, were shown to be perturbed (Table 1). In more detail, Table 2 shows the proteins related to the Nrf-2-pathway and those differentially expressed under both conditions. In particular, a high expression of peroxiredoxins was highlighted, and is discussed below (Table 2). 
Table 1. QIAGEN'S Ingenuity Pathway Analysis: top canonical pathway, disease and biofunctions, and molecular and cellular function.

\begin{tabular}{cc}
\hline Canonical Pathway & $p$-Value \\
\hline PI3K/AKT Signaling & $1.54 \times 10^{-12}$ \\
Cell Cycle: G2/M DNA Damage Checkpoint Regulation & $3.60 \times 10^{-11}$ \\
Nrf-2-mediated Oxidative Stress Response & $4.30 \times 10^{-11}$ \\
\hline Top Tox Lists & $p$-Value \\
\hline Nrf-2-mediated Oxidative Stress Response & $4.98 \times 10^{-14}$ \\
Oxidative Stress & $4.63 \times 10^{-11}$ \\
Hypoxia-Inducible Factor Signaling & $3.60 \times 10^{-3}$ \\
\hline Top Diseases and Biofunctions & $p$-Value \\
\hline Free-Radical Scavenging & $2.89 \times 10^{-4}-2.50 \times 10^{-8}$ \\
Small-Molecule Biochemistry & $3.21 \times 10^{-4}-2.50 \times 10^{-8}$ \\
Cell Death and Survival & $7.12 \times 10^{-4}-3.22 \times 10^{-8}$ \\
\hline
\end{tabular}

Table 2. Differentially expressed proteins in untreated (NT) extracts and in those treated with $\mathrm{Na}_{2} \mathrm{~S}$, identified using label-free nUPLC-MS/MS. ${ }^{1}$ : Protein sequence identifier according to the UniProtKB/Swiss-Prot Protein Knowledgebase; ${ }^{2}$ : protein name; ${ }^{3}$ : ProteinLynx Global Server (PLGS) score; ${ }^{4}$ : protein found highly represented in NT or NaHS extracts; ${ }^{5-7}$ : ratio of expression between NT and $\mathrm{Na}_{2} \mathrm{~S}$.

\begin{tabular}{|c|c|c|c|c|c|c|}
\hline Accession ${ }^{1}$ & Description $^{2}$ & $\begin{array}{c}\text { Score } \\
\text { PLGS }^{3}\end{array}$ & $\begin{array}{c}\text { Highly } \\
\text { Expressed }\end{array}$ & $\begin{array}{l}\text { NT:NaHS } \\
\text { Ratio }^{5}\end{array}$ & $\begin{array}{c}\text { NT:NaHS } \\
\text { Log(e) Ratio }{ }^{6}\end{array}$ & $\begin{array}{c}\text { NT:NaHS Log(e) } \\
\text { Std Dev }{ }^{7}\end{array}$ \\
\hline Q9CQV8 & 14-3-3 protein beta/alpha & 2336.96 & & 1.33 & 0.29 & 0.11 \\
\hline P62259 & 14-3-3 protein epsilon & 992.11 & & 1.03 & 0.03 & 0.19 \\
\hline O70456 & $14-3-3$ protein sigma & 684.53 & & 1.03 & 0.03 & 0.24 \\
\hline P68254 & 14-3-3 protein theta & 895.91 & & 1.24 & 0.22 & 0.11 \\
\hline P20029 & $78 \mathrm{kDa}$ glucose-regulated protein & 635.95 & & 1.12 & 0.11 & 0.09 \\
\hline P11499 & Heat-shock protein HSP 90-beta & 1344.62 & & 1.15 & 0.14 & 0.07 \\
\hline P35700 & Peroxiredoxin-1 & 3181.26 & $\mathrm{NaHS}$ & & & \\
\hline Q61171 & Peroxiredoxin-2 & 898.73 & & 0.9 & -0.1 & 0.08 \\
\hline O008709 & Peroxiredoxin-6 & 566.13 & $\mathrm{NaHS}$ & & & 0.09 \\
\hline P08228 & Superoxide dismutase [Cu-Zn] & 572.41 & & 0.9 & -0.06 & 0.03 \\
\hline 054790 & Transcription factor MafG 1 & 363.28 & $\mathrm{NaHS}$ & & & \\
\hline
\end{tabular}

\subsection{Hydrogen Sulfide Toxicity Operates through Apoptotic and Necroptotic Pathways}

Figure 1 is a representative image of the mixed-culture system that we utilized in our experiments. Spinal-cord cultures were probed with anti-neurofilament H non-phosphorylated (SMI-32, motor neuron; green) and glial fibrillary acidic protein (GFAP, astrocytes; red). We used this system since the interactions between astrocytes and neurons in co-cultures are an important factor for neuronal well-being. Astrocytes are known to release factors that can activate endogenous protective [21] or harmful [22] mechanisms for the neurons. 

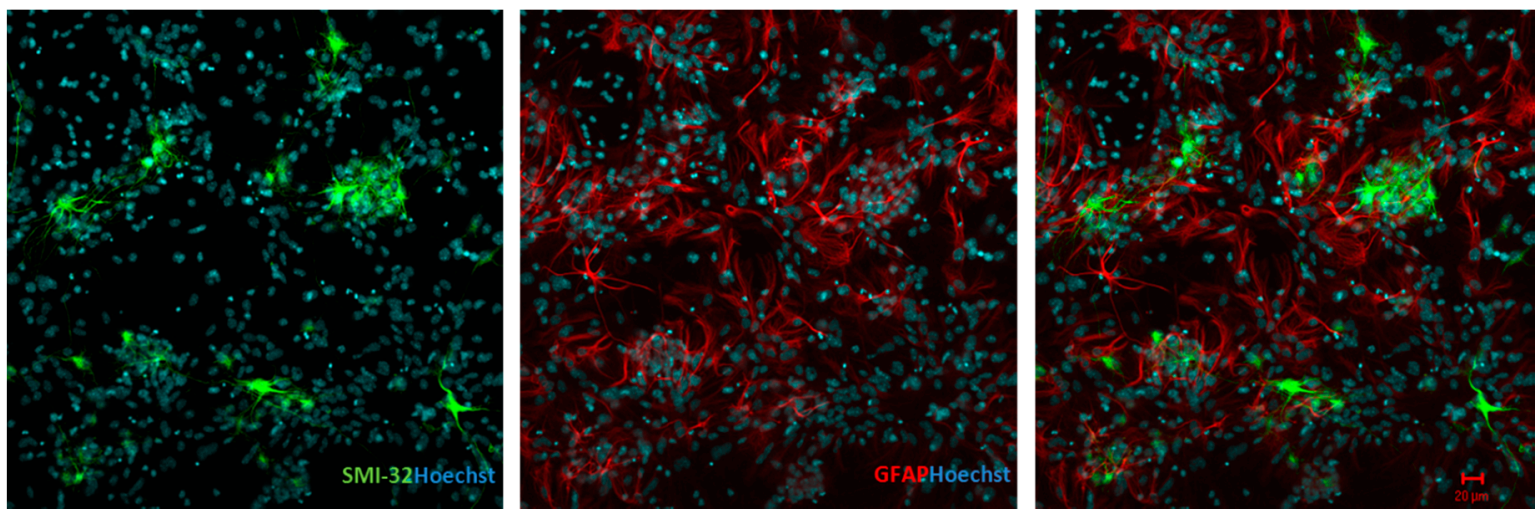

Figure 1. Spinal-cord mixed-culture system at seven days showing immunostaining for SMI-32 (left; green) and GFAP (center; red). The merge is shown in the right panel. Hoescht 322 staining is shown in blue. Scale bars indicate $20 \mu \mathrm{m}$.

Figure 2A shows the cytotoxic effects of the $\mathrm{H}_{2} \mathrm{~S}$ donor, $\mathrm{Na}_{2} \mathrm{~S}$ (sodium sulfide), on motor neurons, confirming NaHS (sodium hydrosulfide) toxicity, as we previously reported [1]. Cytotoxicity of motor neurons due to $\mathrm{Na}_{2} \mathrm{~S}$ was markedly enhanced at the $100 \mu \mathrm{M}$ and $200 \mu \mathrm{M}$ concentrations, with the $200 \mu \mathrm{M}$ concentration reaching a death rate of almost $80 \%$, while the same concentrations of $\mathrm{Na}_{2} \mathrm{~S}$ were not toxic to GFAP+ and Iba-1+ cells (not shown). We then asked whether $\mathrm{H}_{2} \mathrm{~S}$-mediated toxicity operated through the activation of apoptosis, and specifically a Bax-mediated mechanism [23]. Cultures were pretreated with $50 \mu \mathrm{M}$ V5, a synthetic Bax inhibitor peptide, as described in and used by Nagai et al. [21], and then, cultures were co-exposed to $100 \mu \mathrm{M}$ and $200 \mu \mathrm{M} \mathrm{Na}_{2} \mathrm{~S}$ for $18 \mathrm{~h}$. Figure $2 \mathrm{C}$ shows the ability of the Bax inhibitor to revert, at least in part, the death of the SMI-32+ neurons. Its efficacy was clearer against the $200 \mu \mathrm{M} \mathrm{Na} 2 \mathrm{~S}$ concentration (from $24 \pm 7$ to $64 \pm 6$ ), although V5 was also capable of increasing SMI-32+ survival rate by nearly $40 \%$ (from $56 \pm 9$ to $79 \pm 4$ ) vs. the $100 \mu \mathrm{M}$ concentration.

Necroptosis is a newly described form of regulated cell death. It is a regulated form of necrosis which is dependent on the serine/threonine kinase receptor-interacting protein 1 (RIP1) [24]. It is specifically inhibited by a small molecule, necrostatin-1 (Nec-1), which targets RIP1. It was proposed as an additional noxious pathway in ALS-related motor neuron death $[25,26]$. Hence, to explore its involvement in the $\mathrm{H}_{2} \mathrm{~S}$-mediated SMI-32+ neurons, we treated the primary culture under $\mathrm{Na}_{2} \mathrm{~S}$ toxicity $(200 \mu \mathrm{M})$ with Nec-1 at two different concentrations, $5 \mu \mathrm{M}$ and $15 \mu \mathrm{M}$. Nec-1 protection was not as effective as the V5 treatment; however, it was still able to compete against $\mathrm{Na}_{2} \mathrm{~S}$-mediated toxicity, from $24 \pm 7$ to $50 \pm 14$ for the $15 \mu \mathrm{M}$ concentration, and from $24 \pm 7$ to $34 \pm 2$ for the $5 \mu \mathrm{M}$ concentration (Figure 2D). V5 and Nec at $15 \mu \mathrm{M}$ only were not toxic to the SMI-32+ neurons (Figure 2B). These results indicate that both pathways, apoptosis and necroptosis, contribute to $\mathrm{H}_{2} \mathrm{~S}$-induced motor neuron death.

The probing of the cultures with fractin, a specific apoptotic marker [27] of actin fragmentation as a result of caspase-3 activation [28], showed a general increase of its immunopositivity in the cultures (not shown). 
A

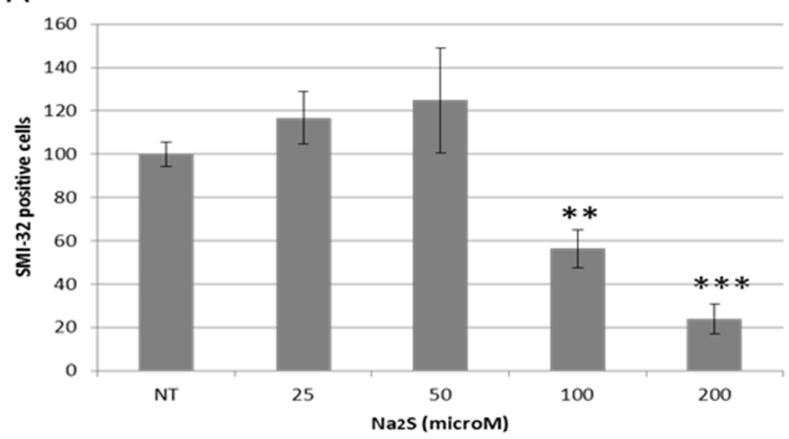

C

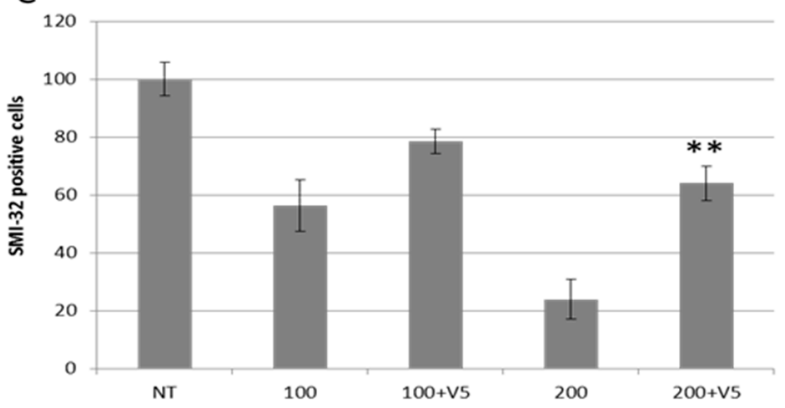

B

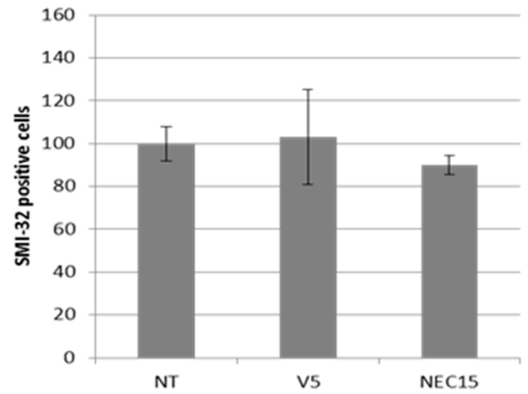

D

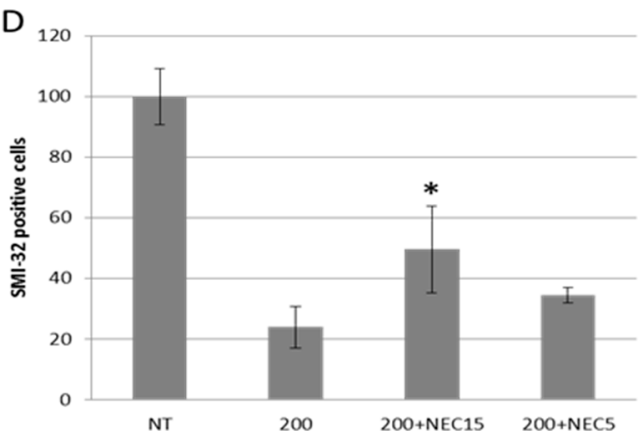

Figure 2. $\mathrm{Na}_{2} \mathrm{~S}$ toxicity in spinal-cord cultures. (A) Mixed spinal-cord cultures were exposed to 25, 50,100 , and $200 \mu \mathrm{M} \mathrm{Na} 2 \mathrm{~S}$. (B) V5 $50 \mu \mathrm{M}$ and necrostatin $15 \mu \mathrm{M}$ were tested alone for their toxicity on spinal-cord cultures. (C) The cultures were exposed to 100 and $200 \mu \mathrm{M} \mathrm{Na} \mathrm{N}_{2} \mathrm{~S}$ plus $50 \mu \mathrm{M}$ V5, and (D) to $200 \mu \mathrm{M} \mathrm{Na} 2 \mathrm{~S}$ plus necrostatin (NEC) 5 and $15 \mu \mathrm{M}$. After $18 \mathrm{~h}$, the number of surviving cells was assessed by direct counting of SMI-32-positive cells, and was normalized to the untreated (NT) values. Data are presented as percentages and as the mean \pm standard error of the mean (SEM) from three experiments counted in triplicate. The values were compared using a $t$-test analysis. ${ }^{* * *} p<0.001$ vs. NT (A), ${ }^{* *} p<0.01$ vs. $200 \mu \mathrm{M} \mathrm{Na}_{2} \mathrm{~S}(\mathbf{A}, \mathbf{C}),{ }^{*} p<0.05$ vs. $200 \mu \mathrm{M} \mathrm{Na} 2 \mathrm{~S}$ (D).

\section{Discussion}

In the presented study, we analyzed the effects of $\mathrm{H}_{2} \mathrm{~S}$ toxicity on mixed primary spinal-cord cultures. Moreover, in order to investigate the changes in protein pathways caused by $\mathrm{H}_{2} \mathrm{~S}$ treatment, we used proteomic analysis based on the MSE isotope label-free approach. The data presented here provide evidence that $\mathrm{H}_{2} \mathrm{~S}$-mediated toxicity triggers the activation of Bax-dependent and necroptosis-dependent pathways. The proteomic analysis indicated that primary spinal-cord cultures respond to $\mathrm{H}_{2} \mathrm{~S}$-mediated toxicity by altering pathways related to the oxidative stress response.

We showed that V5, a cell-permeable apoptosis inhibitor pentapeptide (Val-Pro-Met-Leu-Lys), is effective in protecting motor neurons from $\mathrm{Na}_{2} \mathrm{~S}$-mediated toxicity. A member of the Bcl-2 family of proteins, Bax, is a silent protein that resides in the cytosol. In response to apoptotic stimuli, Bax translocates to the mitochondrial outer membrane, causing the release of apoptogenic factors, like cytochrome c, which, together with the apoptotic protease-activating factor-1 (Apaf-1), forms a critical component of the apoptosome [29-33]. This complex leads to the activation, in an ATP-dependent manner, of caspase-9, which then cleaves and activates caspase-3 and -7 [34].

Recently, an additional programmed cell-death pathway emerged, named necroptosis, which is a form of cell death characterized by an increase in the volume of the cell, organelle swelling, and rupture of the plasma membrane [35]. Necroptosis is considered as an alternative to apoptosis, since it is typically induced when caspase activity is blocked, yet recent evidence indicates that Bax and Bak, responsible for the induction of apoptotic cell death, are involved in the induction/regulation of necroptosis [36-38], although these data are still debated [39,40]. In order to evaluate the contribution 
of this pathway to the mechanism of action of $\mathrm{H}_{2} \mathrm{~S}$, primary spinal-cord cultures were incubated with $\mathrm{Na}_{2} \mathrm{~S}$ in the presence of two concentrations of Nec-1. The targeting of RIP1 was able to partially rescue the SMI-32+ cells, particularly at the highest concentration used (15 $\mu \mathrm{M})$. This result indicates that necroptosis contributes, together with apoptosis, to $\mathrm{H}_{2} \mathrm{~S}$-induced cell insult, and is involved in its cellular toxicity.

The proteomic profile of spinal-cord cultures treated with $\mathrm{Na}_{2} \mathrm{~S}$ here shows that its treatment provokes an upsurge of both oxidative stress and inflammatory pathways (Table 1). We identified, of particular interest, the Nrf-2-mediated oxidative stress response, peroxiredoxins, and hypoxia-inducible factor signaling.

Nrf-2 is one of the main regulators of the antioxidant response. In a state of oxidative stress, it binds to and upregulates the antioxidant response elements (ARE) [41,42], and, in doing so, it triggers the cellular antioxidant and anti-inflammatory defense, and strengthens the mitochondrial protection [43]. The ARE-driven genes are a group of antioxidant and detoxifying enzymes that, when activated, oppose cellular damage in many different tissues and organs [44]. Nrf-2 is linked to several neurodegenerative diseases. In animal models of Huntington's and Parkinson's diseases, the ablation of Nrf-2 worsened cell death [45,46]. Johnson and co-workers, using a transgenic mouse with Nrf-2 expression restricted to astrocytes, reported a significant delay in disease onset and extended life span in a familial model of ALS [47]. Interestingly, the same group reported that, when Nrf-2 is selectively expressed in neurons or type II muscle fibers, only a delayed onset, but not a longer survival, was observed [48]. This further highlights the fundamental role that astrocytes have in the onset and, eventually, in the treatment of ALS as a pharmacologically targeted cell type. Free-radical damage or abnormal free-radical metabolism is widely described in ALS in post-mortem human Central Nervous System tissues and in CSF from ALS patients [49,50]. Moreover, oxidative damage to proteins, lipids, and DNA was described in tissues from sporadic ALS patients and Sod1-linked familial ALS [51,52]. We may infer that the increase in Nrf-2 protein and related pathways under $\mathrm{Na}_{2} \mathrm{~S}$ treatment is an attempt to cope with the toxic environment created by the increase in oxidation and reactive oxygen species (ROS). Interestingly, in our previous work [1], we reported that $\mathrm{H}_{2} \mathrm{~S}$ is mainly a glial product. Nrf-2 and ARE-driven genes co-localize with reactive astrocytes in the symptomatic SOD1G93A mouse spinal cord [53]. In the context of a chronic pathology, the cell may activate multiple, even redundant, systems to cope with inevitable death, such as the over-production of $\mathrm{H}_{2} \mathrm{~S}$ as an anti-inflammatory and anti-apoptotic bio-product, and $\mathrm{Nrf}-2$ as a regulator of the antioxidant response. Hence, while $\mathrm{H}_{2} \mathrm{~S}$ treatment affects the number of SMI-32+ neurons, causing their death, it also triggers the Nrf-2-mediated pathway, which might be seen as an attempt by the surviving cells to cope with $\mathrm{H}_{2} \mathrm{~S}$ toxicity, by setting off an antioxidant response.

Our proteomic analysis also underscored a significant increase in the expression of the peroxiredoxins (PrXs), PrX1, PrX2, and PrX6, in $\mathrm{H}_{2}$ S-treated cultures compared to the untreated cultures (Table 2). High concentrations of $\mathrm{H}_{2} \mathrm{~S}$ are pro-inflammatory. We already demonstrated that a pro-inflammatory lipopolysaccharide (LPS) challenge stimulates the production of $\mathrm{H}_{2} \mathrm{~S}$ in primary spinal-cord cultures [1]. It was speculated that the increased expression of several PrXs in inflammatory situations could be a negative feedback loop response to protect cells against oxidative insult, but could also contribute to the control of redox-sensitive effectors [53,54]. For example, an immunohistochemical study performed on post-mortem sporadic and superoxide dismutase 1 familial ALS human specimens and SOD1 familial ALS mouse models reported that the number of neurons negative for PrX2/glutathione peroxidase-1 (GPxl) increased with ALS disease progression [55]. The authors concluded that the breakdown of this redox system at the advanced disease stage accelerates neuronal degeneration and/or the process of neuronal death. PrXs are regulators of the redox system that is one of the most crucial supporting systems in neurons. PrXs together with glutathione peroxidase-1 (GPxl) form an antioxidant defense system synchronously linked to other important cell-supporting systems. PrXs are major players in inflammatory processes since they act as cytoprotective enzymes against elevated concentrations of ROS/reactive nitrogen species (RNS) generated during inflammation, 
as well as modulators of redox signaling to control, for example, the synthesis and release of inflammatory mediators. They have a clear protective role in inflammation. The increased expression of PrXs could indicate the ability of the surviving cells (for example, the glia population) to activate these protective factors.

Hypoxia-inducible factors (HIFs) are transcription factors that recruit a number of co-activators inside the nucleus, controlling the expression of a series of target genes associated with the control of oxygen homeostasis [56]. HIFs are master regulators of cellular responses. In particular, hypoxia-inducible factor-1 (HIF-1), a heterodimer made of the inducible HIF- $1 \alpha$ subunit and the structural HIF-1 $\beta$ subunit $[57,58]$, is a transcription factor linked to the activation of more than 100 genes involved in angiogenesis, glucose metabolism, cell survival, and metastasis [59,60]. While under normoxia, the HIF- $1 \alpha$ gene is continuously transcribed and translated, while in hypoxic conditions, the HIF- $1 \alpha$ protein accumulates [61]. $\mathrm{H}_{2} \mathrm{~S}$ can substitute oxygen as a substrate of the mitochondrial respiratory chain; however, when its concentration reaches high levels, it becomes a poison and blocks complex IV, leading to a decrease in ATP production, mitochondrial malfunction, and inevitable cell death [62]. Its role in the regulation of HIF-1 factors is somehow elusive, and it varies depending on cell type and experimental conditions [63]. In rat brain capillary endothelial cells, it was described that NaHS increases expression of the HIF- $1 \alpha$ protein and binding activity under $\mathrm{CoCl}_{2}$-induced hypoxia-mimetic conditions [64]. In contrast, NaHS inhibits HIF-1 activation in human hepatoma Hep3B cells, human cervical carcinoma HeLa cells, and human aortic smooth-muscle cells [65]. Our proteomic data indicate that, in our cellular system, $\mathrm{H}_{2} \mathrm{~S}$ treatment increases HIF signaling.

\section{Conclusions}

Taken together, the evidence presented here indicates that the over-production of $\mathrm{H}_{2} \mathrm{~S}$ activates pathways linked to oxidative stress and inflammation. Moreover, we showed that inhibition of the Bax-related pathway can effectively decrease $\mathrm{H}_{2} \mathrm{~S}$-mediated motor neuron death.

Further analyses are needed to understand the role of $\mathrm{H}_{2} \mathrm{~S}$ in spinal-cord homeostasis, and its interaction with inflammation and oxidative stress-related pathways.

Author Contributions: Conceptualization, V.G., A.S. and P.L.; Investigation, V.G., A.S. and P.L.; Methodology, Cell culture studies A.S.; Mass Spectrometry, V.G., V.C.C., L.P. and S.P.; Resources, V.G. and A.U.; Supervision, N.B.M., A.U. and P.L.; Writing-original draft V.G., A.S. and P.L.

Funding: This research was funded by MIUR PRIN 20158EB2CM to A.U. and by the Catholic University of the Sacred Heart intramural research D1.1. to A.U. and V.G.

Acknowledgments: Financial support by MIUR PRIN 20158EB2CM to A.U. and by the Catholic University of the Sacred Heart intramural research D1.1 is acknowledged. We thank Irene Latini (TEFL Certificate) for the English editing.

Conflicts of Interest: The authors declare no conflicts of interest.

\section{References}

1. Davoli, A.; Greco, V.; Spalloni, A.; Guatteo, E.; Neri, C.; Rizzo, G.R.; Cordella, A.; Romigi, A.; Cortese, C.; Bernardini, S.; et al. Evidence of hydrogen sulfide involvement in amyotrophic lateral sclerosis. Ann. Neurol. 2015, 77, 697-709. [CrossRef] [PubMed]

2. Mustafa, A.K.; Gadalla, M.M.; Snyder, S.H. Signaling by gasotransmitters. Sci. Signal. 2009, 28, re2. [CrossRef] [PubMed]

3. Szabo, C. Gastransmitters: New frontiers for translational science. Sci. Transl. Med. 2010, 2, 59 ps54. [CrossRef] [PubMed]

4. Paul, B.D.; Snyder, S.H. Gasotransmitter hydrogen sulfide signaling in neuronal health and disease. Biochem. Pharmacol. 2018, 149, 101-109. [CrossRef] [PubMed]

5. Kimura, H. Signaling molecules: Hydrogen sulfide and polysulfide. Antioxid. Redox Signal. 2015, 22, 362-376. [CrossRef] [PubMed] 
6. Hu, L.F.; Lu, M.; Tiong, C.X.; Dawe, G.S.; Hu, G.; Bian, J.S. Neuroprotective effects of hydrogen sulfide on Parkinson's disease rat models. Aging Cell 2010, 9, 135-146. [CrossRef] [PubMed]

7. Cui, W.; Zhang, Y.; Yang, C.; Sun, Y.; Zhang, M.; Wang, S. Hydrogen sulfide prevents Abeta-induced neuronal apoptosis by attenuating mitochondrial translocation of PTEN. Neuroscience 2016, 325, 165-174. [CrossRef] [PubMed]

8. He, X.L.; Yan, N.; Chen, X.S.; Qi, Y.W.; Yan, Y.; Cai, Z. Hydrogen sulfide down-regulates BACE1 and PS1 via activating PI3K/Akt pathway in the brain of APP/PS1 transgenic mouse. Pharmacol. Rep. 2016, 68, 975-982. [CrossRef] [PubMed]

9. Christia-Lotter, A.; Bartoli, C.; Piercecchi-Marti, M.D.; Demory, D.; Pelissier-Alicot, A.L.; Sanvoisin, A.; Leonetti, G. Fatal occupational inhalation of hydrogen sulfide. Forensic Sci. Int. 2007, 169, 206-209. [CrossRef] [PubMed]

10. Maebashi, K.; Iwadate, K.; Sakai, K.; Takatsu, A.; Fukui, K.; Aoyagi, M.; Ochiai, E.; Nagai, T. Toxicological analysis of 17 autopsy cases of hydrogen sulfide poisoning resulting from the inhalation of intentionally generated hydrogen sulfide gas. Forensic Sci. Int. 2011, 207, 91-95. [CrossRef] [PubMed]

11. Kurokawa, Y.; Sekiguchi, F.; Kubo, S.; Yamasaki, Y.; Matsuda, S.; Okamoto, Y.; Sekimoto, T.; Fukatsu, A.; Nishikawa, H.; Kume, T.; et al. Involvement of ERK in NMDA receptor-independent cortical neurotoxicity of hydrogen sulfide. Biochem. Biophys. Res. Commun. 2011, 414, 727-732. [CrossRef] [PubMed]

12. Cheung, N.S.; Peng, Z.F.; Chen, M.J.; Moore, P.K.; Whiteman, M. Hydrogen sulfide induced neuronal death occurs via glutamate receptor and is associated with calpain activation and lysosomal rupture in mouse primary cortical neurons. Neuropharmacology 2007, 53, 505-514. [CrossRef] [PubMed]

13. Spalloni, A.; Albo, F.; Ferrari, F.; Mercuri, N.; Bernardi, G.; Zona, C.; Longone, P. Cu/Zn-superoxide dismutase (GLY93 $\rightarrow$ ALA) mutation alters AMPA receptor subunit expression and function and potentiates kainate-mediated toxicity in motor neurons in culture. Neurobiol. Dis. 2004, 2, 340-350. [CrossRef] [PubMed]

14. Piras, C.; Soggiu, A.; Greco, V.; Martino, P.A.; Del Chierico, F.; Putignani, L.; Urbani, A.; Nally, J.E.; Bonizzi, L.; Roncada, P. Mechanisms of antibiotic resistance to enrofloxacin in uropathogenic Escherichia coli in dog. J. Proteom. 2015, 127, 365-376. [CrossRef] [PubMed]

15. Piras, C.; Guo, Y.; Soggiu, A.; Chanrot, M.; Greco, V.; Urbani, A.; Charpigny, G.; Bonizzi, L.; Roncada, P.; Humblot, P. Changes in protein expression profiles in bovine endometrial epithelial cells exposed to E. coli LPS challenge. Mol. Biosyst. 2017, 13, 392-405. [CrossRef] [PubMed]

16. Silva, J.C.; Gorenstein, M.V.; Li, G.Z.; Dissers, J.P.; Geromanos, S.J. Absolute quantification of proteins by LCMSE a virtue of parallel MS acquisition. Mol. Cell. Proteom. 2006, 5, 144-156. [CrossRef] [PubMed]

17. Vissers, J.P.; Langridge, J.I.; Aerts, J.M. Analysis and quantification of diagnostic serum markers and protein signatures for Gaucher disease. Mol. Cell. Proteom. 2007, 6, 755-766. [CrossRef] [PubMed]

18. Kimura, Y.; Kimura, H. Hydrogen sulfide protects neurons from oxidative stress. FASEB J. 2004, 18, $1165-1167$. [CrossRef] [PubMed]

19. Nagai, Y.; Tsugane, M.; Oka, J.; Kimura, H. Hydrogen sulfide induces calcium waves in astrocytes. FASEB J. 2004, 18, 557-559. [CrossRef] [PubMed]

20. Marutani, E.; Yamada, M.; Ida, T.; Tokuda, K.; Ikeda, K.; Kai, S.; Shirozu, K.; Hayashida, K.; Kosugi, S.; Hanaoka, K.; et al. Thiosulfate Mediates Cytoprotective Effects of Hydrogen Sulfide Against Neuronal Ischemia. J. Am. Heart Assoc. 2015, 4. [CrossRef]

21. Cui, W.; Allen, N.D.; Skynner, M.; Gusterson, B.; Clark, A.J. Inducible ablation of astrocytes shows that these cells are required for neuronal survival in the adult brain. Glia 2001, 34, 272-282. [CrossRef] [PubMed]

22. Ising, C.; Heneka, M.T. Functional and structural damage of neurons by innate immune mechanisms during neurodegeneration. Cell Death Dis. 2018, 25, 120. [CrossRef] [PubMed]

23. Nagai, M.; Re, D.B.; Nagata, T.; Chalazonitis, A.; Jessell, T.M.; Wichterle, H.; Przedborski, S. Astrocytes expressing ALS-linked mutated SOD1 release factors selectively toxic to motor neurons. Nat. Neurosci. 2007, 10, 615-622. [CrossRef] [PubMed]

24. Fayaz, S.M.; Suvanish Kumar, V.S.; Rajanikant, G.K. Necroptosis: Who knew there were so many interesting ways to die? CNS Neurol. Disord. Drug Targets 2014, 13, 42-51. [CrossRef] [PubMed]

25. Re, D.B.; Le Verche, V.; Yu, C.; Amoroso, M.W.; Politi, K.A.; Phani, S.; Ikiz, B.; Hoffmann, L.; Koolen, M.; Nagata, T.; et al. Necroptosis drives motor neuron death in models of both sporadic and familial ALS. Neuron 2014, 81, 1001-1008. [CrossRef] [PubMed] 
26. Ito, Y.; Ofengeim, D.; Najafov, A.; Das, S.; Saberi, S.; Li, Y.; Hitomi, J.; Zhu, H.; Chen, H.; Mayo, L.; et al. RIPK1 mediates axonal degeneration by promoting inflammation and necroptosis in ALS. Science 2016, 353, 603-608. [CrossRef] [PubMed]

27. Yang, F.; Sun, X.; Beech, W.; Teter, B.; Wu, S.; Sigel, J.; Vinters, H.V.; Frautschy, S.A.; Cole, G.M. Antibody to caspase-cleaved actin detects apoptosis in differentiated neuroblastoma and plaque-associated neurons and microglia in Alzheimer's diseases. Am. J. Pathol. 1998, 152, 379-389. [PubMed]

28. Suurmeijer, A.J.; van der Wijk, J.; van Veldhuisen, D.; Yang, F.; Cole, G.M. Fractin immunostaining for the detection of apoptotic cells and apoptotic bodies in Formalin-fixed and paraffin-embedded tissues. Lab. Investig. 1999, 79, 619-620. [PubMed]

29. Li, P.; Nijhawan, D.; Budihardjo, I.; Srinivasula, S.M.; Ahmad, M.; Alnemri, E.S.; Wang, X. Cytochrome c and dATP-dependent formation of Apaf-1/caspase-9 complex initiates an apoptotic protease cascade. Cell 1997, 91, 479-489. [CrossRef]

30. Zou, H.; Henzel, W.J.; Liu, X.; Lutschg, A.; Wang, X. Apaf-1, a human protein homologous to C. elegans CED-4, participates in cytochrome c-dependent activation of caspase-3. Cell 1997, 90, 405-413. [CrossRef]

31. Jurgensmeier, J.M.; Xie, Z.; Deveraux, Q.; Ellerby, L.; Bredesen, D.; Reed, J.C. Bax directly induces release of cytochrome c from isolated mitochondria. Proc. Natl. Acad. Sci. USA 1998, 95, 4997-5002. [CrossRef] [PubMed]

32. Lovell, J.F.; Billen, L.P.; Bindner, S.; Shamas-Din, A.; Fradin, C.; Leber, B.; Andrews, D.W. Membrane binding by tBid initiates an ordered series of events culminating in membrane permeabilization by Bax. Cell 2008, 135, 1074-1084. [CrossRef] [PubMed]

33. Shore, G.C.; Nguyen, M. Bcl-2 proteins and apoptosis: Choose your partner. Cell 2008, 35, $1004-1006$. [CrossRef] [PubMed]

34. Lakhani, S.A.; Masud, A.; Kuida, K.; Porter, G.A., Jr.; Booth, C.J.; Mehal, W.Z.; Inayat, I.; Flavell, R.A. Caspases 3 and 7: Key mediators of mitochondrial events of apoptosis. Science 2006, 311, 847-851. [CrossRef] [PubMed]

35. Galluzzi, L.; Kepp, O.; Chan, F.K.; Kroemer, G. Necroptosis: Mechanisms and Relevance to Disease. Annu. Rev. Pathol. 2017, 12, 103-130. [CrossRef] [PubMed]

36. Irrinki, K.M.; Mallilankaraman, K.; Thapa, R.J.; Chandramoorthy, H.C.; Smith, F.J.; Jog, N.R.; Gandhirajan, R.K.; Kelsen, S.G.; Houser, S.R.; May, M.J.; et al. Requirement of FADD, NEMO, and BAX/BAK for aberrant mitochondrial function in tumor necrosis factor alpha-induced necrosis. Mol. Cell. Biol. 2011, 18, 3745-3758. [CrossRef] [PubMed]

37. Karch, J.; Kanisicak, O.; Brody, M.J.; Sargent, M.A.; Michael, D.M.; Molkentin, J.D. Necroptosis Interfaces with MOMP and the MPTP in Mediating Cell Death. PLoS ONE 2015, 10, e0130520. [CrossRef] [PubMed]

38. Rohde, K.; Kleinesudeik, L.; Roesler, S.; Löwe, O.; Heidler, J.; Schröder, K.; Wittig, I.; Dröse, S.; Fulda, S.A. Bak-dependent mitochondrial amplification step contributes to Smac mimetic/glucocorticoid-induced necroptosis. Cell Death Differ. 2017, 24, 83-97. [CrossRef] [PubMed]

39. Tait, S.W.; Oberst, A.; Quarato, G.; Milasta, S.; Haller, M.; Wang, R.; Karvela, M.; Ichim, G.; Yatim, N.; Albert, M.L.; et al. Widespread mitochondrial depletion via mitophagy does not compromise necroptosis. Cell Rep. 2013, 5, 878-885. [CrossRef] [PubMed]

40. Linkermann, A.; Bräsen, J.H.; Darding, M.; Jin, M.K.; Sanz, A.B.; Heller, J.O.; De Zen, F.; Weinlich, R.; Ortiz, A.; Walczak, H.; et al. Two independent pathways of regulated necrosis mediate ischemia-reperfusion injury. Proc. Natl. Acad. Sci. USA 2013, 110, 12024-12029. [CrossRef] [PubMed]

41. Johnson, J.A.; Johnson, D.A.; Kraft, A.D.; Calkins, M.J.; Jakel, R.J.; Vargas, M.R.; Chen, P.C. The Nrf2-ARE pathway: An indicator and modulator of oxidative stress in neurodegeneration. Ann. N. Y. Acad. Sci. 2008, 1147, 61-69. [CrossRef] [PubMed]

42. Shih, A.Y.; Imbeault, S.; Barakauskas, V.; Erb, H.; Jiang, L.; Li, P.; Murphy, T.H. Induction of the Nrf2-driven antioxidant response confers neuroprotection during mitochondrial stress in vivo. J. Biol. Chem. 2005, 280, 22925-22936. [CrossRef] [PubMed]

43. Hybertson, B.M.; Gao, B.; Bose, S.K.; McCord, J.M. Oxidative stress in health and disease: The therapeutic potential of Nrf2 activation. Mol. Asp. Med. 2011, 32, 234-246. [CrossRef] [PubMed]

44. Calkins, M.J.; Jakel, R.J.; Johnson, D.A.; Chan, K.; Kan, Y.W.; Johnson, J.A. Protection from mitochondrial complex II inhibition in vitro and in vivo by Nrf2-mediated transcription. Proc. Natl. Acad. Sci. USA 2005, 102, 244-249. [CrossRef] [PubMed] 
45. Innamorato, N.G.; Jazwa, A.; Rojo, A.I.; García, C.; Fernández-Ruiz, J.; Grochot-Przeczek, A.; Stachurska, A.; Jozkowicz, A.; Dulak, J.; Cuadrado, A. Different susceptibility to the Parkinson's toxin MPTP in mice lacking the redox master regulator Nrf2 or its target gene heme oxygenase-1. PLoS ONE 2010, 5, e11838. [CrossRef] [PubMed]

46. Vargas, M.R.; Johnson, D.A.; Sirkis, D.W.; Messing, A.; Johnson, J.A. Nrf2 activation in astrocytes protects against neurodegeneration in mouse models of familial amyotrophic lateral sclerosis. J. Neurosci. 2008, 28, 13574-13581. [CrossRef] [PubMed]

47. Vargas, M.R.; Burton, N.C.; Kutzke, J.; Gan, L.; Johnson, D.A.; Schäfer, M.; Werner, S.; Johnson, J.A. Absence of Nrf2 or its selective overexpression in neurons and muscle does not affect survival in ALS-linked mutant hSOD1 mouse models. PLoS ONE 2013, 8, e56625. [CrossRef]

48. Shaw, P.J.; Ince, P.G.; Falkous, G.; Mantle, D. Oxidative damage to protein in sporadic motor neuron disease spinal cord. Ann. Neurol. 1995, 38, 691-695. [CrossRef] [PubMed]

49. Smith, R.G.; Henry, Y.K.; Mattson, M.P.; Appel, S.H. Presence of 4-hydroxynonenal in cerebrospinal fluid of patients with sporadic amyotrophic lateral sclerosis. Ann. Neurol. 1998, 44, 696-699. [CrossRef] [PubMed]

50. Shibata, N.; Nagai, R.; Miyata, S.; Jono, T.; Horiuchi, S.; Hirano, A.; Kato, S.; Sasaki, S.; Asayama, K.; Kobayashi, M. Nonoxidative protein glycation is implicated in familial amyotrophic lateral sclerosis with superoxide dismutase-1 mutation. Acta Neuropathol. 2000, 100, 275-284. [CrossRef] [PubMed]

51. Shibata, N.; Nagai, R.; Uchida, K.; Horiuchi, S.; Yamada, S.; Hirano, A.; Kawaguchi, M.; Yamamoto, T.; Sasaki, S.; Kobayashi, M. Morphological evidence for lipid peroxidation and protein glycoxidation in spinal cords from sporadic amyotrophic lateral sclerosis patients. Brain Res. 2001, 917, 97-104. [CrossRef]

52. Kraft, A.D.; Resch, J.M.; Johnson, D.A.; Johnson, J.A. Activation of the Nrf2-ARE pathway in muscle and spinal cord during ALS-like pathology in mice expressing mutant SOD1. Exp. Neurol. 2007, 207, $107-117$. [CrossRef] [PubMed]

53. Perkins, A.; Nelson, K.J.; Parsonage, D.; Poole, L.B.; Karplus, P.A. Peroxiredoxins: Guardians against oxidative stress and modulators of peroxide signaling. Trends Biochem. Sci. 2015, 40, 435-445. [CrossRef] [PubMed]

54. Knoops, B.; Argyropoulou, V.; Becker, S.; Ferté, L.; Kuznetsova, O. Multiple Roles of Peroxiredoxins in Inflammation. Mol. Cells 2016, 39, 60-64. [PubMed]

55. Kato, M.; Kato, S.; Abe, Y.; Nishino, T.; Ohama, E.; Aoki, M.; Itoyama, Y. Histological recovery of the hepatocytes is based on the redox system upregulation in the animal models of mutant superoxide dismutase (SOD)1-linked amyotrophic lateral sclerosis. Histol. Histopathol. 2006, 21, 729-742. [PubMed]

56. Wenger, R.H. Cellular adaptation to hypoxia: $\mathrm{O}_{2}$-sensing protein hydroxylases, hypoxia-inducible transcription factors, and $\mathrm{O}_{2}$-regulated gene expression. FASEB J. 2002, 16, 1151-1162. [CrossRef] [PubMed]

57. Wang, G.L.; Jiang, B.H.; Rue, E.A.; Semenza, G.L. Hypoxia-inducible factor 1 is a basic-helix-loop-helix-PAS heterodimer regulated by cellular O2 tension. Proc. Natl. Acad. Sci. USA 1995, 92, 5510-5514. [CrossRef] [PubMed]

58. Yang, Y.; Sun, M.; Wang, L.; Jiao, B. HIFs, angiogenesis, and cancer. J. Cell. Biochem. 2013, 114, 967-974. [CrossRef] [PubMed]

59. Semenza, G.L. Hypoxia pathway linked to kidney failure. Nat. Med. 2006, 12, 996-997. [CrossRef] [PubMed]

60. Spagnuolo, R.D.; Recalcati, S.; Tacchini, L.; Cairo, G. Role of hypoxia-inducible factors in the dexrazoxane-mediated protection of cardiomyocytes from doxorubicin-induced toxicity. Br. J. Pharmacol. 2011, 163, 299-312. [CrossRef] [PubMed]

61. Yee Koh, M.; Spivak-Kroizman, T.R.; Powis, G. HIF-1 regulation: Not so easy come, easy go. Trends Biochem. Sci. 2008, 33, 526-534. [CrossRef] [PubMed]

62. Cuevasanta, E.; Möller, M.N.; Alvarez, B. Biological chemistry of hydrogen sulfide and persulfides. Arch. Biochem. Biophys. 2017, 617, 9-25. [CrossRef] [PubMed]

63. Wu, B.; Teng, H.; Zhang, L.; Li, H.; Li, J.; Wang, L.; Li, H. Interaction of Hydrogen Sulfide with Oxygen Sensing under Hypoxia. Oxid. Med. Cell. Longev. 2015, 2015, 758678. [CrossRef] [PubMed] 
64. Liu, X.; Pan, L.; Zhuo, Y.; Gong, Q.; Rose, P.; Zhu, Y. Hypoxia-inducible factor-1 $\alpha$ is involved in the pro-angiogenic effect of hydrogen sulfide under hypoxic stress. Biol. Pharm. Bull. 2010, 33, 1550-1554. [CrossRef] [PubMed]

65. Kai, S.; Tanaka, T.; Daijo, H.; Harada, H.; Kishimoto, S.; Suzuki, K.; Takabuchi, S.; Takenaga, K.; Fukuda, K.; Hirota, K. Hydrogen sulfide inhibits hypoxia- but not anoxia-induced hypoxia-inducible factor 1 activation in a von hippel-lindau- and mitochondria-dependent manner. Antioxid. Redox Signal. 2012, 16, 203-216. [CrossRef] [PubMed]

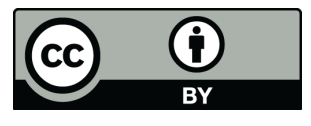

(c) 2018 by the authors. Licensee MDPI, Basel, Switzerland. This article is an open access article distributed under the terms and conditions of the Creative Commons Attribution (CC BY) license (http:/ / creativecommons.org/licenses/by/4.0/). 